\title{
Pieces of the puzzle
}

\section{After decades of war, looting and destruction, Afghanistan's archaeologists are scrambling to restore their country's cultural heritage. Rex Dalton visited Kabul to see how they are faring.}

F rom a hillside overlooking Kabul, a dozen Afghan archaeology students have a monumental vista of their nation's ancient heritage. Domes of tombs of past kings dot the skyline; a stone wall topped with battlements snakes along a ridge; and nearby looms the fifth-century AD fortress Bala Hissar, site of countless battles and events, including the massacre of a British envoy and his staff about 125 years ago and the retaliatory series of public hangings of Afghans.

But it is a less dramatic, century-old home site, on a knoll on the hillside, that is getting the attention today. Afghan archaeologist Zemaryalai Tarzi, of Strasbourg University in France, has brought the students here to teach them basic excavation skills. The group was to have been the inaugural class of Afghanistan's first graduate programme in archaeology at Kabul University. But instead it has turned into an impromptu field school; the challenges of setting up a master's programme in the country are too great now.

It is six years since the fall of the Taliban regime, the force that routinely and ruthlessly smashed artefacts it deemed idols. And although normality is returning to many parts of Afghan life, archaeologists are still struggling to recover the country's heritage and rebuild its academic community. The threat of violence keeps many researchers from doing field projects, as funding agencies often ban archaeologists from going out to sites. Looted artefacts are being recovered, but only slowly. Many artefacts that did make it through the strife - including a priceless collection of gold relics, called the Bactrian hoard - are now being exhibited abroad, although critics claim that Afghanistan is not being sufficiently compensated.

Taliban memories haunt nearly every aspect

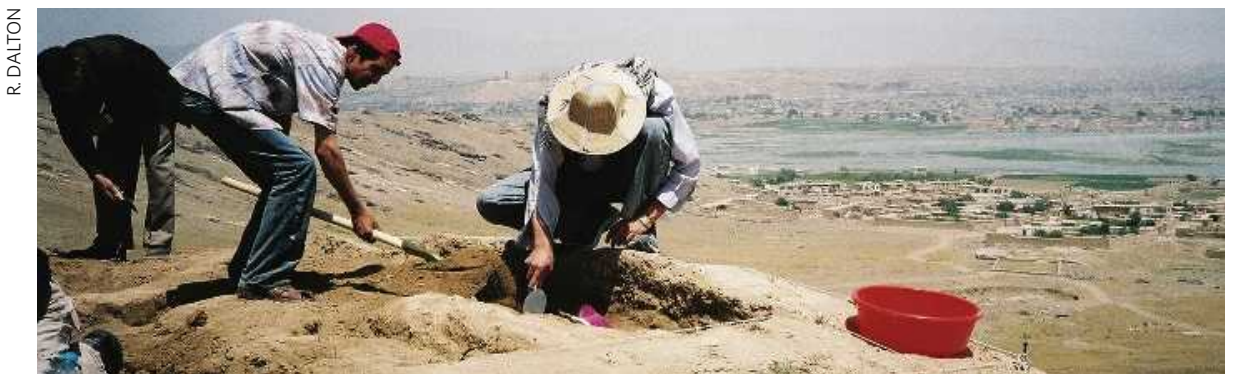

Students practise techniques for archaeological excavation on a hilltop overlooking Kabul.

of Tarzi's instructional dig. The excavation site lies below a steep-walled, rocky gorge that cuts to the top of a high ridge and also holds a spring, a source of fresh water for the poor community just down the hillside. There, supplied with water that could be traded for food, the Taliban set up a command post from which to strategically control the western approach to Kabul. "No one could come here during Taliban days," says Hafiz Latify, an assistant at the Afghan Institute of Archaeology now studying in Greece, as we climb to meet Tarzi's group.

\section{Kidnap threat}

But the spectre of violence has returned. Tarzi has suspended the dig because of security concerns; travelling to the site, along dirt alleys through the teeming city of Kabul, has become too dangerous. With the kidnapping of French citizens in Afghanistan earlier this year, officials in France, where Tarzi now lives and works, say he can conduct studies next summer only in Bamiyan, where the situation is more secure. Over the years, Tarzi's excavations at Bamiyan, about 125 kilometres west of Kabul, have yielded an array of artefacts, including life-like sculpted heads modelled after individuals from the past two millennia. But he wants to return to Kabul so that he can resume his teaching efforts.

In some areas of Kabul, though, reconstruction is already under way. West over the ridge from Tarzi's instructional dig, the Afghan national museum in Kabul has undergone a transformation. The museum was ransacked

under Taliban rule, and statues were pounded into smithereens in a rampage that did not garner as many headlines as the destruction of the huge Buddha statues at Bamiyan. By the time they left, "the museum was a depressing ruin - no roof, no glass, everything broken into little pieces", says Gitta van Buuren, a Dutch cultural anthropologist who has visited Kabul since 2003 to document the city's recovery photographically.

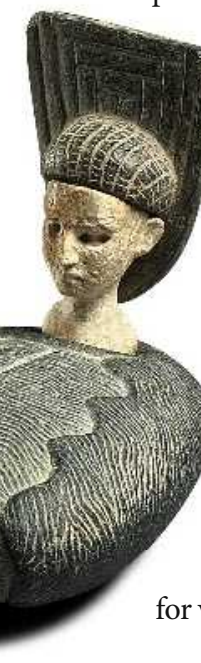
for visitc visitors - although few come - and in a laboratory on the second floor, museum staff spread out broken pieces, putting artefacts and statues back together like jigsaw puzzles. The pieces fill buckets. But the staff is turning them back into life-like forms, and the restored statues are making their way downstairs along with other salvaged objects. Omara Khan Masoudi, the museum's director, says the restoration team is making progress, but is short-staffed when it comes to skilled workers. "We need more Afghans - or any scientist - to help," he says.

Facing such realities, Afghanistan has turned to touring some of its most precious artefacts in international museums. Afghanistan's key treasures include the Bactrian hoard - about 21,600 gold coins, ornaments, pieces of jewellery and funerary relics - discovered in northern Afghanistan in 1978 at a 2,000-yearold burial site called Tillia Tepe. They reflect a mélange of styles - from Greek to those of Asian tribes.

When the Taliban tightened authoritarian screws, archaeologists worldwide feared these relics were lost. But in 2003, the Bactrian hoard 


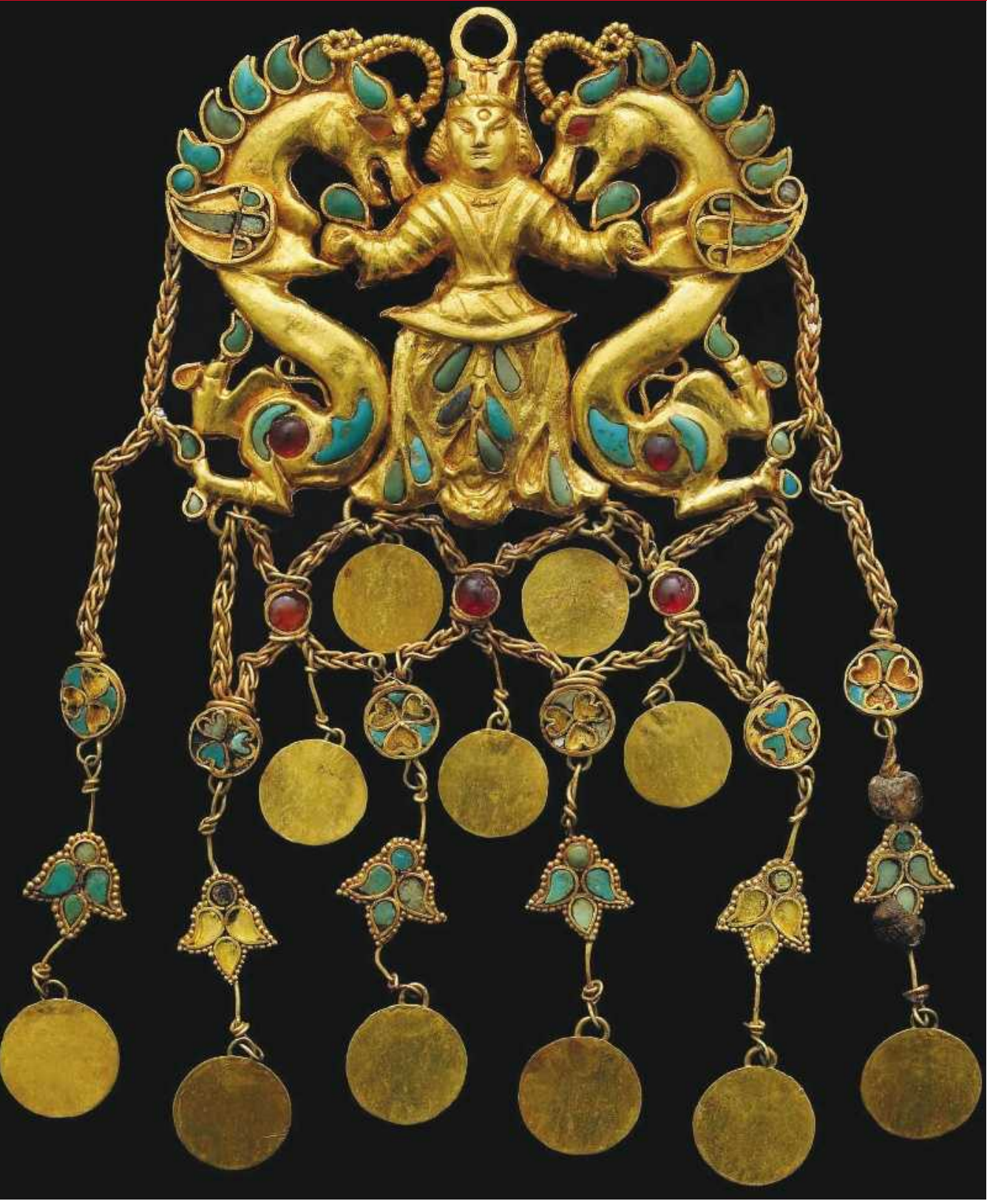

On the road: more than 200 spectacular Afghan treasures are currently touring the world.

emerged from a vault of the central bank in Kabul, where it had been successfully secreted away from the Taliban. After inventory and cataloguing, the gold artefacts went on the global museum circuit.

In the past year, more than 200 artefacts from the Bactrian collection have been exhibited in Paris, and Turin in Italy. On 22 December, the exhibition is to open at the Nieuwe Kerk in Amsterdam, the Netherlands, in what is being called a 'blockbuster show', before moving to a US tour that takes in Washington DC, San Francisco, Houston and New York. But simmering behind the glitz is anger and resentment about whether the Afghans are being properly compensated. "The Afghans were taken advantage of," charges Lynne Munson, a former deputy director of the US National Endowment for the Humanities, who helped arrange endowment funding for the Bactrian inventory.

The European exhibitions typically paid about $€ 150,000$ (US\$220,000) to Afghanistan; in Paris and Turin, about 130,000 people visited the exhibition, at an admission fee of $€ 8$ apiece. The four upcoming US exhibitions - potentially the richest revenue producer - are to provide the Afghans with a total loan fee of $\$ 1$ million. The Afghans will also receive $40 \%$ of merchandise sales, after expenses, for the US tour.

\section{Making the deal}

Munson argues that the Afghans should have received substantially more, and she worries that they will see nothing from the merchandise deal given the way it is structured for payments after expenses. She blames the US tour's organizer, the venerable National Geographic Society, which will receive any additional monies from the tour. "They took advantage of the Afghans for their own selfishness," she says.

But Terry Garcia, an executive vice-president of the National Geographic Society, says his organization worked hard to make sure the
Afghans were getting a good deal, and modelled US financial arrangements on those of the European tour. "Throughout every step of the process, we have responded to the needs and wishes of the Afghans," he says.

Munson also says that she recently learned that the document lending the artefacts was signed on behalf of the Afghan government by Omar Sultan, who took on the responsibilities of acting minister for the Afghan culture ministry after the minister was injured in a bombing. But Sultan has also worked as a paid consultant to National Geographic. "It's a conflict of interest," says Munson. The arrangement has been debated and criticized in the Afghan parliament, although Garcia says the negotiations had the full support of the Afghan government.

The need for funds is desperate, says Ana Rosa Rodriguez, executive director of the Society for the Preservation of Afghanistan's Cultural Heritage. Her group, based in Kabul, trains staff and raises funds to protect sites by actions such as trying to restrict detrimental development at the 'city castle' of Bala Hissar. More money would translate into more conservation, she says.

But some Afghan supporters say that sending the nation's artefacts on tour is a good idea - as there is limited security to protect them at the Kabul museum. Afghan artefacts of suspicious provenance - potentially sneaked out during the Soviet or Taliban years, or even since - regularly show up for sale at international auction houses. In April, the International Council of Museums (ICOM) in Paris presented a 'red list' guide to Afghan artefacts that may appear for sale illegally. Afghan treasures that have been up for auction have been scrutinized, but the list hasn't yet resulted in any seizures by law-enforcement agencies such as Interpol, says ICOM's Jennifer Thevenot. This isn't surprising, as both the ICOM and Interpol have skeleton staffs for looking into questionable artefacts. If an auction house has legitimate-looking documents, an artefact is likely to be sold with little inquiry.

In November, for instance, the Boisgirard auction house in Paris offered two Bactrian sculptures at prices of up to US\$100,000. Thevenot says that questions were asked, but no action was taken because the house had documents. No one contacted Afghan experts such as Tarzi, who helped to draw up the red list.

The items were sold, disappearing into a private collection much as they might once have gone down the old Silk Road. Those trying to save Afghanistan's culture hope that it doesn't all follow that route.

Rex Dalton is a US West Coast correspondent for Nature. 